\title{
A ONE-WAY VALVED ATRIAL SEPTAL PATCH: A NEW SURGICAL TECHNIQUE AND ITS CLINICAL APPLICATION
}

\author{
N. Ad, MD \\ E. Birk, $\mathrm{MD}^{\mathrm{b}}$ \\ J. Barak, MD \\ S. Diamant, $\mathrm{MD}^{\mathrm{c}}$ \\ E. Snir, MD \\ B. A. Vidne, $M^{a}$
}

\begin{abstract}
Patients who undergo surgical repair of congenital heart defects, characterized by a hypoplastic right ventricle or high pulmonary vascular resistance, are at high risk for the development of postoperative right heart failure. This risk may discourage the surgical team from carrying out a biventricular or complete repair in such patients. To reduce the risk for right heart failure, we developed a one-way, valved, atrial septal patch to serve as an artificial one-way foramen ovale and tested it in an animal model. By permitting right-to-left shunt, this device decompresses the failing right ventricle and maintains systemic cardiac output. The device has been used in 15 patients divided into three different groups: group 1 ( $n=8$ ), patients with a hypoplastic right ventricle and pulmonic stenosis or atresia, seven of whom underwent a biventricular repair; group $2(n=5)$, patients with evidence of pulmonary disease after longstanding left-to-right shunt caused by a correctable atrial or ventricular septal defect, all of whom had a complete repair; group 3, two patients with acute right heart failure in whom the device was used as a last option of treatment to wean them from cardiopulmonary bypass. This article presents our data in regard to the use of the one-way, valved, atrial septal patch and the indications for its clinical use. (J THORAC CardiovasC Surg 1996;111:841-8)
\end{abstract}

$T^{1}$ he correction of congenital heart defects characterized by a hypoplastic right ventricle (RV) or high pulmonary vascular resistance is frequently associated with postoperative failure of the right side of the heart. ${ }^{1,2}$ The risk of heart failure may discourage the surgical team from carrying out a biventricular or complete repair in these patients. Should postoperative right heart failure supervene, conventional medical therapy may not always improve the hemodynamic state. ${ }^{3-6}$ The creation of an atrial septal defect (ASD) under these circumstances may dramatically improve the patient's condition and prognosis. Right-to-left interatrial shunting reduces RV preload and simultaneously augments left ven-

From the Departments of Cardiothoracic Surgery and Pediatric Cardiology, ${ }^{\mathrm{b}}$ Beilinson Medical Center, the Department of Cardiothoracic Surgery, ${ }^{c}$ Tel Aviv Medical Center, and the Sackler Faculty of Medical Sciences, Tel Aviv University, Tel Aviv, Israel.

Received for publication Feb. 1, 1995; accepted for publication May 18, 1995.

Address for reprints: B. A. Vidne, MD, Head, Department of Cardiothoracic Surgery, Beilinson Medical Center, Petach Tikva 49100, Israel.

Copyright (C) 1996 by Mosby-Year Book, Inc.

$0022-5223 / 96 \$ 5.00+0 \quad \mathbf{1 2 / 1 / 6 6 3 3 3}$ tricular (LV) preload and cardiac output. Tissue oxygen delivery is improved, despite the mild arterial blood desaturation resulting from the ASD. By decreasing RV preload, such shunting also improves coronary blood flow to the failing $\mathrm{RV} .^{7-11}$

The major disadvantage of this surgical solution, however, is that the ASD will require closure by a subsequent invasive procedure. Reoperation may be avoided by the use of a one-way, valved, atrial septal patch that can serve as an artificial patent foramen ovale. We $\mathrm{e}^{12}$ developed such a device and successfully tested it in an animal study.

We present herein the results of our first clinical series using the one-way, valved, atrial septal patch.

\section{Methods}

Surgical procedure. The device is fashioned in two layers, one of polytetrafluoroethylene* and the other of woven Dacron polyester. A central circular opening, 3 to $4 \mathrm{~mm}$ in diameter, ${ }^{13,14}$ is created in the polytetrafluoroethylene layer and covered by a second smaller layer of woven Dacron polyester ("curtain"). The curtain is sutured to the polytetrafluoroethylene along one side only, thus creating a simple, one-way valve. Two side stitches

\footnotetext{
* Gore-Tex cardiovascular patch, registered trademark of W. L. Gore \& Associates, Inc., Newark, Del.
} 

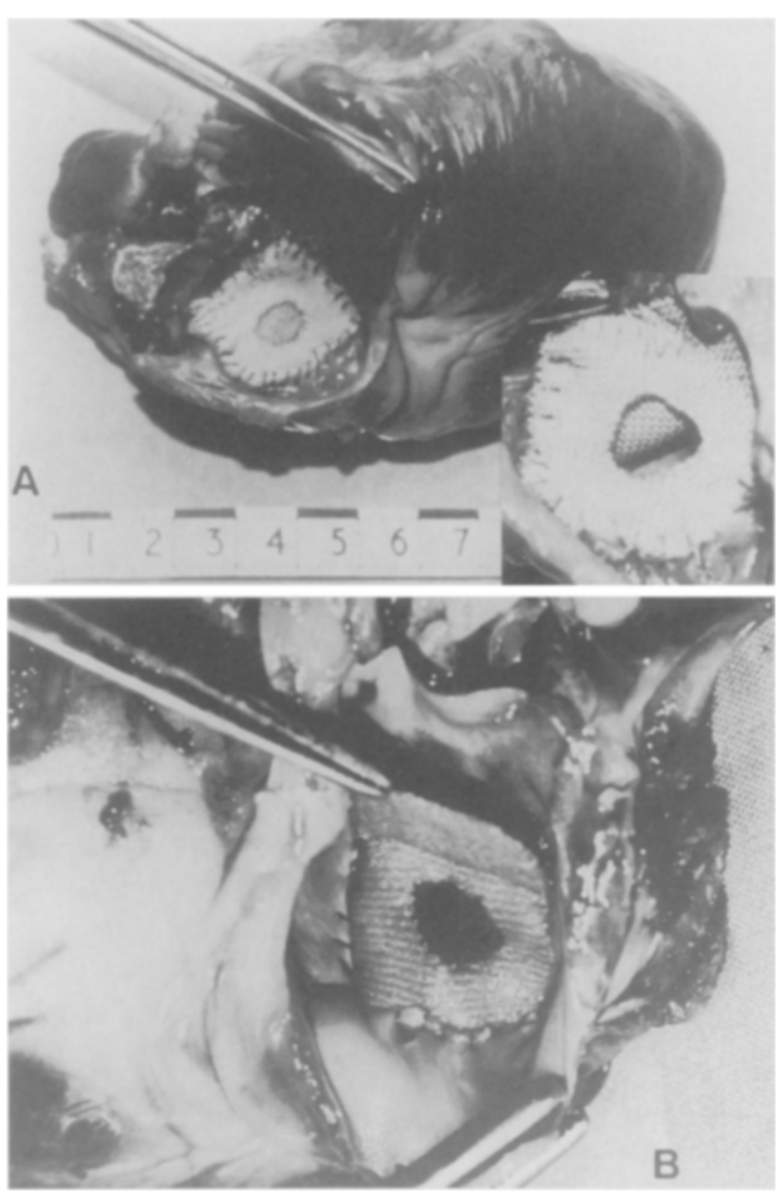

Fig. 1. The one-way, valved, atrial septal patch. A, A view through a right atriotomy. The "curtain" is being lifted by forceps (animal model). B, A view through a left atriotomy (animal model).

are inserted and are important for maintaining the curtain in the correct position for closure. ${ }^{12}$

The device is sutured to the interatrial septum through the right atrium so that the curtain faces the left atrium and closes toward the right atrium (Fig. 1).

Patients. Between 1989 and 1994, we used the one-way, valved, atrial septal patch in 15 patients (11 female and 4 male patients) divided into three groups according to their congenital malformation and clinical state: group $1(n=$ 8 ), patients with a hypoplastic RV, small tricuspid valve, and severe pulmonic stenosis or atresia (Table I); group 2 $(n=5)$, patients with high pulmonary vascular resistance because of a large left-to-right shunt from an ASD or ventricular septal defect (VSD) (Table II); and group 3 $(n=2)$, patients with intraoperative acute right heart failure after complete repair of the congenital malformations. The right heart failure in group 3 was resistant to maximal pharmacologic treatment, and the one-way, valved, atrial septal patch was implanted as a last resort and only after repeated failures to wean the patients from cardiopulmonary bypass (CPB) (Table III).

\section{Results}

All patients in groups 1 and 2 survived the operation and are alive at present. In no patient in this series was there any morbidity that could be ascribed to the use of the one-way, valved, atrial septal patch. At discharge, all patients received aspirin as prophylaxis against thrombus formation on the device, as well as prophylaxis against subacute bacterial endocarditis. During the follow-up period, neither thrombus formation nor subacute bacterial endocarditis was documented.

Group 1 (Table IV). The presence of a right-toleft interatrial shunt could be demonstrated in all patients in this group by echocardiography immediately after weaning from $\mathrm{CPB}$. As early as this stage, RV function was impaired to varying degrees.

The first four patients had pulmonic atresia with intact ventricular septum and a moderately small RV. All had previously undergone surgical procedures to establish and maintain RV-pulmonary artery continuity and systemic-pulmonary artery shunting (see Table I). At follow-up periods of 3 months to 4 years, an open device with a right-to-left shunt could be demonstrated in these patients.

Two patients required a subsequent surgical intervention.

Patient 5 had a hypoplastic RV with severe pulmonic stenosis and a VSD. She underwent RV outflow tract reconstruction with closure of the VSD and installation of the one-way, valved, atrial septal patch. Fifteen months after the operation, because of severe RV failure and marked cyanosis, she underwent a total cavopulmonary connection. The patient is doing well.

Patient 7 had transposition of the great arteries, subpulmonic stenosis, and a VSD. She underwent a Rastelli operation and installation of the one-way, valved, atrial septal patch. The device remained open for 3 months and then spontaneously closed. Three years after this operation, the one-way, valved, atrial septal patch reopened as a result of the development of severe stenosis in the RV-pulmonary artery conduit (pressure $=70 \mathrm{~mm} \mathrm{Hg}$ ). At reoperation the conduit was replaced, and the one-way, valved, atrial septal patch closed immediately thereafter.

Group 2 (Table V). Because of the high probability that postoperative right heart failure will develop in group 2 patients, the one-way, valved, atrial septal patch was inserted as a safety valve. The device closed spontaneously in all patients except patient 1 during the first postoperative week as RV pressures diminished. 
Table I. Patient data-group 1

\begin{tabular}{|c|c|c|c|c|}
\hline Patient & Age & Sex & Diagnosis & Previous operation \\
\hline 1 & $10 \mathrm{mo}$ & $\mathrm{M}$ & $\begin{array}{l}\text { PA-IVS, hypoplastic RV, } \\
\text { PDA }\end{array}$ & $\begin{array}{l}\text { Modified B-T shunt, atrial } \\
\text { septostomy, pulmonary } \\
\text { valvotomy }\end{array}$ \\
\hline 2 & $8 \mathrm{yr}$ & $\mathrm{F}$ & $\begin{array}{l}\text { PA-IVS, hypoplastic RV, very } \\
\text { small TV }\end{array}$ & $\begin{array}{l}\text { Modified B-T shunt, atrial } \\
\text { septostomy, central shunt, } \\
\text { RVOT reconstruction }\end{array}$ \\
\hline 3 & $8 \mathrm{yr}$ & $\mathrm{F}$ & PA-IVS, hypoplastic RV & $\begin{array}{l}\text { Modified B-T shunt, atrial } \\
\text { septostomy, central shunt, } \\
\text { RVOT reconstruction }\end{array}$ \\
\hline 4 & $1.5 \mathrm{yr}$ & $\mathrm{M}$ & $\begin{array}{l}\text { PA-IVS, hypoplastic RV, } \\
\text { PDA }\end{array}$ & $\begin{array}{l}\text { Central shunt, pulmonary } \\
\text { valvotomy, PDA ligation }\end{array}$ \\
\hline 5 & $3.5 \mathrm{yr}$ & $\mathrm{F}$ & $\begin{array}{l}\text { Hypoplastic RV, severe PS, } \\
\text { VSD, right-to-left shunt, } \\
\text { Qp/Qs } 0.7: 1\end{array}$ & \\
\hline 6 & $13.5 \mathrm{yr}$ & $\mathrm{F}$ & $\begin{array}{l}\text { Hypoplastic RV, VSD, ASD, } \\
\text { severe PS, right-to-left } \\
\text { shunt, Qp/Qs } 0.8: 1\end{array}$ & PA banding \\
\hline 7 & $13.5 \mathrm{yr}$ & $\mathrm{F}$ & $\begin{array}{l}\text { TGA, small RV, small TV, } \\
\text { severe PS, LPSVC. }\end{array}$ & Glenn shunt \\
\hline 8 & $5 \mathrm{yr}$ & $\mathrm{F}$ & TOF, small RV, small PA & \\
\hline
\end{tabular}

$P A-I V S$, Pulmonic atresia and intact ventricular septum; $R V$, right ventricle; $P D A$, patent ductus arteriosus; $T V$, tricuspid valve; $P S$, pulmonic stenosis; $Q s / Q p$, systemic/pulmonary flow ratio; $V S D$, ventricular septal defect; $A S D$, atrial septal defect; $T G A$, transposition of the great arteries; $L P S V C$, left persistent superior vena cava; TOF, tetralogy of Fallot; $P A$, pulmonary artery; $B-T$, Blalock-Taussig; $R V O T$, right ventricular outflow tract.

Table II. Patient data-group 2

\begin{tabular}{|c|c|c|c|c|c|c|c|c|}
\hline \multirow[b]{2}{*}{ Patient } & \multirow[b]{2}{*}{ Sex } & \multirow[b]{2}{*}{ Age } & \multirow[b]{2}{*}{ Diagnosis } & \multicolumn{2}{|c|}{$P V R\left(U / m^{2}\right)$} & \multicolumn{2}{|c|}{$Q p / Q s$} & \multirow{2}{*}{$\begin{array}{c}\text { Previous } \\
\text { operation }\end{array}$} \\
\hline & & & & Room air & $100 \% \mathrm{O}_{2}$ & Room air & $100 \% \mathrm{O}_{2}$ & \\
\hline 1 & $\mathrm{~F}$ & $23 \mathrm{yr}$ & $\begin{array}{l}\text { Large VSD, } \\
\text { PDA, bidirec- } \\
\text { tional shunt }\end{array}$ & 7.1 & 7.0 & $2: 1$ & $2: 1$ & \\
\hline 2 & $\mathrm{~F}$ & $29 \mathrm{yr}$ & $\begin{array}{c}\text { ASD secundum, } \\
\text { bidirectional } \\
\text { shunt }\end{array}$ & 14.1 & 4.2 & $1.6: 1$ & $2.8: 1$ & \\
\hline 3 & $\mathrm{~F}$ & $31 \mathrm{yr}$ & Large VSD & 5.5 & 5.0 & $1.36: 1$ & $2: 1$ & $\begin{array}{l}\text { Ligation } \\
\text { of PDA }\end{array}$ \\
\hline 4 & M & $\begin{array}{c}2.5 \\
\mathrm{yr}\end{array}$ & $\begin{array}{c}\text { ASD secundum, } \\
\text { LPSVC }\end{array}$ & 4.4 & 1.6 & $1.5: 1$ & $2: 1$ & \\
\hline 5 & F & $\begin{array}{r}2.5 \\
\text { yr }\end{array}$ & $\begin{array}{l}\text { ASD primum, } \\
\text { cleft } M V\end{array}$ & 4.2 & 4.2 & 2.8:1 & $2.8: 1$ & \\
\hline
\end{tabular}

$P V R$, Pulmonary vascular resistance; $Q p / Q s$, pulmonary/systemic flow ratio; VSD, ventricular septal defect; $P D A$, patent ductus arteriosus; $A S D$, atrial septal defect; $L P S V C$, left persistent superior vena cava; $M V$, mitral valve.

In patient 1 , the device remained open for 8 months after the operation and then closed spontaneously. Early in the postoperative period, a right-to-left shunt and an arterial oxygen saturation of $88 \%$ were noted (Fig. 2). At that time a suprasystemic pulmonary artery pressure of $180 / 70 \mathrm{~mm} \mathrm{Hg}$ was recorded. The patient's postoperative course was uneventful and she was discharged from the hospital after 14 days. Eighteen weeks later, the arterial oxygen saturation was $94 \%$ at rest. Eight months after the operation, the one-way, valved, atrial septal patch had closed spontaneously.
The arterial oxygen saturation was $98 \%$ and the pulmonary artery pressure as estimated by echocardiography was $75 / 35 \mathrm{~mm} \mathrm{Hg}$. RV contractility was good, with the interventricular septum in the middle position. The patient's general condition was satisfactory and her physical capacity had improved significantly (New York Heart Association [NYHA] functional capacity class I).

Group 3. Both patients in group 3 died during the operation. In patient 1 , installation of the device resulted in a significant reduction in the RV pres- 
Table III. Patient data-group 3

\begin{tabular}{|c|c|c|c|c|}
\hline Patient & Age & $\operatorname{Sex}$ & Diagnosis & Previous operation \\
\hline 1 & $15 \mathrm{mo}$ & M & $\begin{array}{l}\text { TOF, severely hypoplastic } \\
\text { and distorted PAs }\end{array}$ & $\begin{array}{l}\text { Complete repair of TOF and PAs; } \\
\text { assisted ventilation owing to } \\
\text { residual PA stenosis }\end{array}$ \\
\hline 2 & $6 \mathrm{mo}$ & $\mathrm{F}$ & $\begin{array}{c}\text { Large VSD, PVR }=9 \\
\text { Wu, Qp/Os }=1.5: 1 \\
\text { systemic PA pressure }\end{array}$ & \\
\hline
\end{tabular}

$T O F$, Tetralogy of Fallot; $P A$, pulmonary artery; $V S D$, ventricular septal defect; $P V R$, pulmonary vascular resistance; $Q_{p} / Q s$, pulmonary/systemic flow ratio.

Table IV. Results-group 1

\begin{tabular}{|c|c|c|c|}
\hline Patient & Surgical procedure & Patency of the patch & Further intervention \\
\hline 1 & Biventricular repair & $\begin{array}{l}4 \text { yr postop.-open; } \mathrm{O}_{2} \text { sat. } \\
96 \% \text { at rest; } 92 \% \text { after exer- } \\
\text { cise }\end{array}$ & \\
\hline 2 & $\begin{array}{l}\text { Bidirectional Glenn TV } \\
\text { commisurotomy }\end{array}$ & $\begin{array}{l}5 \text { mo postop.-open; } \mathrm{O}_{2} \text { sat } \\
90 \%\end{array}$ & \\
\hline 3 & Insertion of the patch alone & $\begin{array}{l}5 \text { mo postop--open; } \mathrm{O}_{2} \text { sat } \\
90 \%\end{array}$ & \\
\hline 4 & RVOT reconstruction & $\begin{array}{l}3 \text { mo postop.-open; } \mathrm{O}_{2} \text { sat } \\
92 \%\end{array}$ & \\
\hline 5 & $\begin{array}{l}\text { Biventricular repair, RVOT } \\
\text { reconstruction, and clo- } \\
\text { sure of VSD }\end{array}$ & $\begin{array}{l}15 \text { mo postop.--wide open; big } \\
\text { right-to-left shunt; RHF in- } \\
\text { duced by closure of patch by } \\
\text { a balloon }\end{array}$ & $\begin{array}{l}\text { TCPC, } 15 \text { mo after the first } \\
\text { operation; good results }\end{array}$ \\
\hline 6 & $\begin{array}{l}\text { Closure of VSD and de- } \\
\text { banding of main PA }\end{array}$ & $\begin{array}{l}3 \text { mo postop.-open; } 1 \mathrm{yr} \\
\text { postop-functionally open } \\
\text { without a shunt }\end{array}$ & \\
\hline 7 & Rastelli operation & $\begin{array}{l}3 \text { mo postop-closed; } 3 \text { yr } \\
\text { postop-reopened due to } \\
\text { severe stenosis in RV-PA } \\
\text { conduit; } \Delta \text { pressure }=70 \\
\text { mm Hg }\end{array}$ & $\begin{array}{l}\text { Reoperation for the replace- } \\
\text { ment of the RV-PA con- } \\
\text { duit, reclosure of the patch }\end{array}$ \\
\hline 8 & Complete repair & 6 wk postop.-closed & \\
\hline
\end{tabular}

$T V$, tricuspid valve; patch, one-way, valved, atrial septal patch; RVOT, right ventricular outflow tract; VSD, ventricular septal defect; $P A$, pulmonary artery; $R H F$, right heart failure; $R V$, right ventricle; $P A$, pulmonary artery; $T C P C$, total cavopulmonary connection.

sure, but he could not be weaned from CPB. In patient 2 , installation of the device did not result in any improvement in the infant's hemodynamic state, and she too could not be weaned from CPB.

\section{Discussion}

Group 1. Except in patient 2, the one-way, valved, atrial septal patch enabled us to perform a biventricular repair in all patients in this group. All of them had a hypoplastic RV and pulmonary artery tree (see Table I), and the risk of biventricular repair was considered to be high.

Patients 1 to 4, with pulmonary atresia and intact ventricular septum, presented a special challenge. The thorny question remains as to who are the best candidates for a biventricular repair. ${ }^{15-18}$ Among our patients, all had mild to moderate RV hypopla- sia and could therefore be considered possible candidates for biventricular repair. ${ }^{15,18}$ As mentioned in the Results section, all patients in this group had $\mathrm{RV}$ dysfunction immediately after being weaned from CPB, and the open device at this stage probably facilitated weaning from CPB and eased their postoperative course.

In patient 1 , who has a follow-up of 4 years, the device was used as part of a biventricular repair and has not closed, and the right-to-left shunt has been documented throughout this period. The arterial oxygen saturation, however, which was $85 \%$ to $88 \%$ in the early postoperative period, has increased to $96 \%$ at rest 4 years later. This may be related in part to improved RV function, as well as to narrowing in the fenestration aperture, whose diameter was $4 \mathrm{~mm}$ at the time of the operation. During an exercise test, 

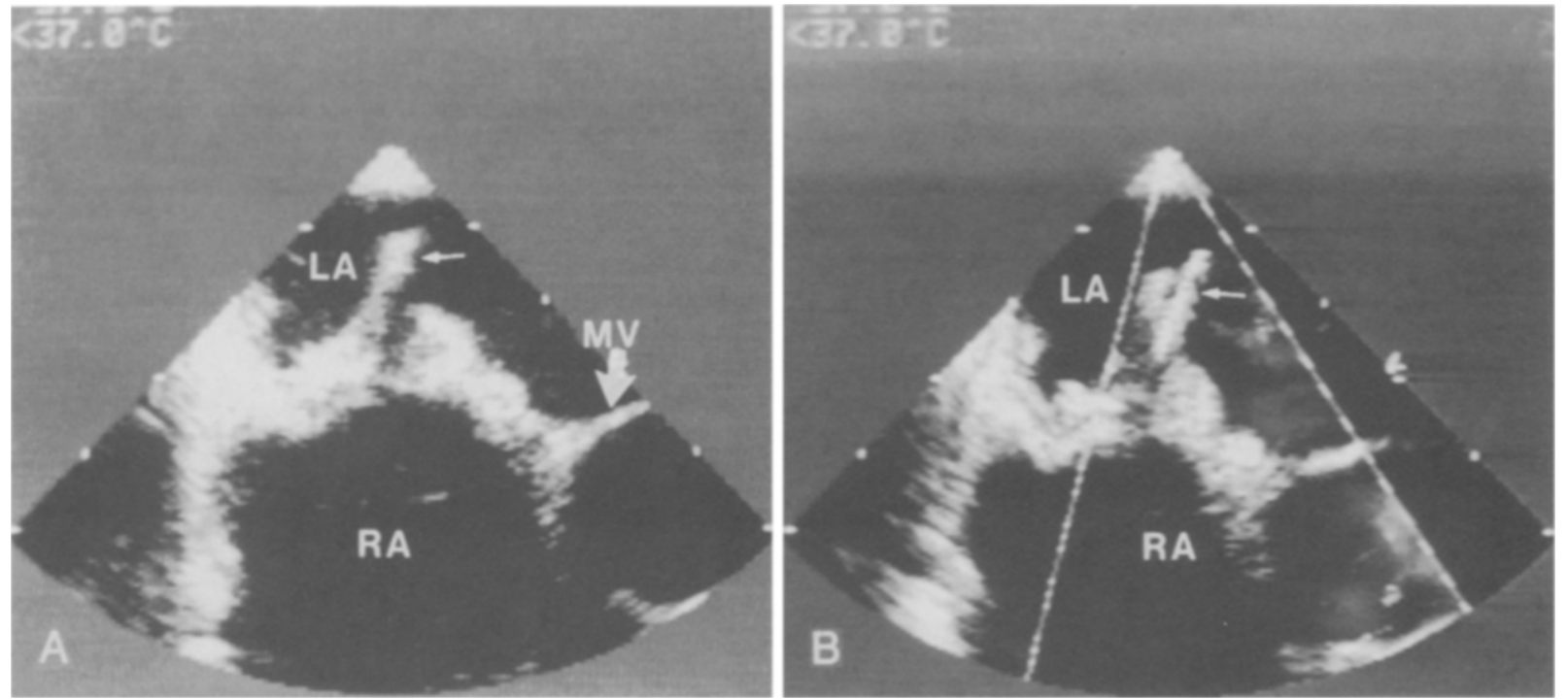

Fig. 2. Thin arrow, the open "curtain" of the one-way, valved, patch (A) and the right-to-left shunt through it (B). $R A$, Right atrium; $L A$, left atrium; $M V$, mitral valve.

Table V. Results-group 2

\begin{tabular}{|c|c|c|}
\hline Patient & Surgical procedure & Patency of patch \\
\hline 1 & $\begin{array}{l}\text { Closure of VSD, division of } \\
\text { PDA, and installation of patch }\end{array}$ & 8 mo postop.-closed \\
\hline 2 & $\begin{array}{l}\text { Closure of ASD and installation } \\
\text { of patch }\end{array}$ & 1 wk postop.-closed \\
\hline 3 & $\begin{array}{l}\text { Closure of VSD and installation } \\
\text { of patch }\end{array}$ & $\begin{array}{l}\text { No shunt through } \\
\text { patch in early } \\
\text { postop. state }\end{array}$ \\
\hline 4 & $\begin{array}{l}\text { Closure of ASD with patch and } \\
\text { repair of PAVC }\end{array}$ & 1 wk postop-—closed \\
\hline 5 & $\begin{array}{l}\text { Closure of ASD with patch and } \\
\text { repair of cleft MV }\end{array}$ & $1 \mathrm{wk}$ postop.-closed \\
\hline
\end{tabular}

$\overline{V S D}$, ventricular septal defect; $P D A$, patent ductus arteriosus; patch, one-way, valved, atrial septal patch; $\overline{A S D}$, atrial septal defect; $M V$, mitral valve; $P A V C$, partial atrioventricular correction. No further operations were performed.

the arterial blood saturation diminished to $93 \%$, and on simultaneous echocardiography RV function was shown to be poorer than at rest. These results demonstrate that despite a successful biventricular repair and good NYHA functional class, RV function may still be impaired especially during effort, when a right-to-left interatrial shunt serves to maintain cardiac output and systemic oxygen delivery. ${ }^{12}$ This child is doing well, with NYHA class I cardiac function, and attends a normal school.

Patients 2 to 4 were all operated on during the past 6 months and all still have an open device with a right-to-left shunt (see Table IV). The arterial blood saturation values in these three patients are $90 \%$ to $92 \%$. Preoperatively, all had arterial blood saturations of $60 \%$ to $65 \%$. As in the case of patient 1 , we believe that the arterial oxygen saturation will increase further in the future. The one-way, valved, atrial septal patch may yet close, but should it remain open, as in patient 1 , its presence will be important to decompress the $\mathrm{RV}$ and maintain cardiac output when necessary.

Patient 5 underwent total cavopulmonary connection 15 months after the first operation and she is now progressing well. Review of this patient's data revealed that she had a hypoplastic RV and a tricuspid valve whose diameter was half the normal size. The pulmonary arteries were of normal size and without significant systemic-pulmonary collaterals. After the initial repair, there was no significant 
gradient across the pulmonic valve $(3 \mathrm{~mm} \mathrm{Hg})$, the $\mathrm{RV} / \mathrm{LV}$ pressure ratio was 0.7 , and the device was open, permitting right-to-left shunting. However, the RV function deteriorated. The device remained open with a big right-to-left shunt and marked cyanosis. An attempted balloon closure of the device aggravated the degree of $\mathrm{RV}$ failure and prompted the decision to perform a total cavopulmonary connection. We therefore do not consider this to be a failure of the device, but rather an error in patient selection for the biventricular repair. The open device in this instance served to decompress the failing RV and possibly helped to avoid a catastrophic result from the illchosen biventricular repair. ${ }^{19}$

Patient 7, with transposition of the great arteries, VSD, and subpulmonic stenosis, underwent a Rastelli operation and installation of the one-way, valved, atrial septal patch, despite a Nakata index ${ }^{20}$ of $168 \mathrm{~mm}^{2} / \mathrm{m}^{2}$. We consider that the use of the device enabled us to perform a Rastelli operation in this patient. Three months after the operation, the one-way, valved, atrial septal patch closed. Three years later, the device reopened because of elevation of the right-sided pressures, and the right-toleft shunt was detected. The pressures became elevated as a result of the development of severe stenosis in the RV-pulmonary artery conduit, which was replaced during a subsequent operation. After this procedure, the device again closed spontaneously and the patient is now doing well. In this instance, the device demonstrated the advantages of (1) early postoperative RV decompression and (2) the ability to reopen several years later when elevated right-sided pressures supervened.

Patient 8, who had tetralogy of Fallot, small pulmonary arteries, and a Nakata index ${ }^{20}$ of $138 \mathrm{~mm}^{2} / \mathrm{m}^{2}$, underwent a complete repair with installation of the one-way, valved, atrial septal patch. Her postoperative course was uneventful and the device closed spontaneously after 6 weeks. Four years later, the device remains closed and she is in NYHA functional class $I$.

The principle of leaving a patent foramen ovale when repairing a high-risk tetralogy of Fallot has been advocated in the past. ${ }^{21}$ The use of the device in this high-risk condition facilitated complete repair and undoubtedly eased the postoperative course.

Group 2. All patients in group 2 had a correctable ASD or VSD with significant pulmonary vascular disease and were in NYHA functional class of III or IV (see Table II). This kind of patient also presents a particular challenge to the surgical team, and the decision as to whether to operate is difficult because of the high risk of perioperative acute right heart failure. ${ }^{22}$ Surgery for the correction of an ASD should be performed before the age of 5 years if there is a significant left-to-right shunt with a pulmonary/systemic flow ratio greater than 2 . In the presence of pulmonary hypertension with an elevated pulmonary vascular resistance, the patient should not be operated on if the resistance is more than $9 \mathrm{U} / \mathrm{m}^{2}$ and cannot be reduced below $8 \mathrm{U} / \mathrm{m}^{2}$ with pulmonary vasodilator agents. ${ }^{22-24}$ VSD correction should not be performed because of the same hazard, when a fixed pulmonary vascular resistance of $8 \mathrm{U} / \mathrm{m}^{2}$ or greater is measured. ${ }^{25}$

Patients 1 to 3 were adults whose conditions were considered inoperable in other centers, but whom we regarded as on the borderline for the safe correction of the septal defect with a one-way, valved, atrial septal patch.

Patient 1 was in NYHA functional class IV on admission, requiring an oxygen mask intermittently. The pulmonary vascular resistance was fixed a level of $7.1 \mathrm{U} / \mathrm{m}^{2}$ with a bidirectional shunt. At operation a complete repair of the VSD was performed, the one-way, valved, atrial septal patch was installed in the interatrial septum, and the patent ductus arteriosus was ligated and divided. Lung biopsy revealed grade 1 to 3 changes according to the classification of Heath and Edwards, ${ }^{26}$ and these changes are considered to be reversible. ${ }^{27}$ As described in the Results section, a progressive fall in the pulmonary artery pressure occurred over the initial postoperative 8 months, with significant improvement in RV function. This led to the spontaneous closure of the device and an arterial oxygen saturation of $98 \%$. In addition, her general condition has improved and she is now in NYHA functional class I; the only medication she receives is aspirin. According to this patient's data, we consider that the use of the device made the operation possible and eased the postoperative course. In the light of the still high pulmonary artery pressure $(73 / 35 \mathrm{~mm} \mathrm{Hg})$, the spontaneous closure of the device might be considered premature. However, the fact that at least part of her pulmonary vascular disease was reversible according to the lung biopsy is reassuring, and we hope for further improvement in her pulmonary artery pressure and RV function.

Patient 2 had an ASD, a pulmonary vascular resistance of $14.2 \mathrm{U} / \mathrm{m}^{2}$, and a bidirectional shunt while breathing room air. While she was breathing $100 \%$ oxygen, pulmonary vascular resistance was $4.2 \mathrm{U} / \mathrm{m}^{2}$ and the pulmonary/systemic flow ratio rose from 1.6:1 
to 2.8:1. At operation, the ASD was repaired with the one-way, valved, atrial septal patch. A right-to-left shunt was documented for the first 6 postoperative days, when spontaneous closure occurred.

We considered this patient's condition to be on the borderline for surgical correction, ${ }^{22}$ but many might have regarded her condition as inoperable. After 4.5 years of follow-up, the device remains closed and she is in NYHA functional class I.

From the hemodynamic data of patient 3 (see Table II), we considered her to be at high risk for the development of perioperative right heart failure without the use of the one-way, valved, atrial septal patch. Her perioperative course was, in fact, uneventful, and transesophageal echocardiography revealed no shunt through the device, although the RV/LV peak pressure ratio was 0.9 after weaning from CPB. These findings can be explained by the fact that when RV function is still good despite these circumstances, with a near normal RV end-diastolic pressure $(13 \mathrm{~mm} \mathrm{Hg})$, elevation of the right atrial pressure is minimal and the pressure gradient between the right and left atria is not sufficiently high to open the one-way, valved, atrial septal patch. ${ }^{12}$

In the future, we would still consider such a patient to be a candidate for correction of the VSD, with installation of the device at the interatrial septum as a safety valve against the development of right heart failure.

In patients 4 and 5 the ASDs were corrected with the device. In both, the device closed spontaneously 1 week after the operation.

In patient 4 , the device was used as part of the surgical repair to reduce the risk of right heart failure in a patient who had a relatively small left-to-right shunt despite a large ASD. We suspected that the preoperative hemodynamic measurements (see Table II) might be erroneous in the face of such a large ASD, as demonstrated on echocardiography and cardiac catheterization.

Patient 5 was a very ill baby with severe failure to thrive and a large ASD. The pulmonary vascular resistance was high and fixed (see Table II), and we considered the risk of surgery to be very high. As in the other cases in this group, we believe that the device eased the perioperative course, and we can highly recommend its use in such infants.

Group 3. Use of the device as a last resort to wean both patients in this group from CPB proved unsuccessful. In patient 1 , the use of the device resulted in decompression of the RV. Initially, the pressure in the RV was suprasystemic; installation of the device resulted in a significant reduction of the RV pressure to less than half of LV pressure. Despite this improvement, the patient could not be weaned from CPB. In patient 2 , the device did not improve her hemodynamic state and we were unable to wean her from CPB.

Despite its use, the one-way, valved, atrial septal patch failed in this group and both patients died. Instead of prolonged use of CPB with repeated and unsuccessful efforts to wean the patient, we think that the device should be installed as soon as right heart failure resistant to conventional treatment occurs. ${ }^{3-6}$ If the device was installed promptly, decompression of the failing RV and better cardiac output would be achieved sooner with a better prospect of weaning from CPB. Earlier placement of the device may also prevent further insult from a very long extracorporeal circulation time and poor hemodynamic state to the heart, lungs, and other organs. $^{28}$

The creation of an ASD to allow right-to-left interatrial shunting is not a new concept in dealing with right heart failure. ${ }^{7-10}$ Such a shunt serves to decompress the failing RV and augments cardiac output at the expense of mild arterial blood desaturation. Decompression of the RV and reduction in its end-diastolic pressure improves coronary blood flow to the failing myocardium. ${ }^{11}$ Despite the mild arterial blood desaturation, tissue oxygen delivery improves as a result of increased cardiac output. Although well established, this concept is not sufficiently exploited to reduce the risk of postoperative right heart failure and thus enable a biventricular or complete repair to be undertaken in borderline cases. ${ }^{10,15}$ The fenestrated Fontan procedure uses this principle, although as part of a univentricular repair. ${ }^{29}$ However, we do not consider the one-way, valved, atrial septal patch to be suitable for such an operation because of the obligatory high pressures in the right-sided conduit, which will maintain the device in its open position.

The one-way, valved, atrial septal patch provides the same hemodynamic benefits as an ASD, together with the added advantages of a controlled opening pressure and the ability to close, without the need for a subsequent invasive procedure. Furthermore, the device does not permit any left-toright shunt and thus prevents vena caval congestion if the left atrial pressures exceed those on the right side. ${ }^{12,30}$ Should the RV pressure again become elevated, as occurred in patient 7 in group 1, the device may reopen after its initial closure and thus 
also serve as a safety valve on the right side later in the postoperative period. Theoretically, if the device remains open, not because of a hemodynamic state, which obligates the right-to-left shunt, but because of a mechanical problem, such as a panus formation, then the use of a clamshell device to achieve closure is possible. However, in our limited experience no such problem occurred.

When there are indications for its use, the oneway, valved, atrial septal patch as part of the surgical repair may prevent postoperative right heart failure, ease the early postoperative course, and further improve operative results. We recommend the use of aspirin and prophylaxis to combat subacute bacterial endocarditis when the device is used as part of the surgical repair.

\section{REFERENCES}

1. Kirklin JW, Blackstone EH, Shimasaki Y, et al. Survival, functional status, and reoperation after repair of tetralogy of Fallot with pulmonary atresia. J THORAC CARDIOvASC SURG 1988;96:102-16.

2. Gonzales AC, Brandon TA, Fortune $\mathrm{KL}$, et al. Acute right ventricular failure is caused by inadequate right ventricular hypothermia. J Thorac Cardiovasc Surg 1985;89: 386-99.

3. Spence PA, Weisel RD, Salerno TA. Right ventricular failure: pathophysiology and treatment. Surg Clin North Am 1985;65:689-97.

4. Cohn JN, Guiha NH, Broder MI, Limas CJ. Right ventricular infarct: clinical and hemodynamic features. Am J Cardiol 1974;33:209-14.

5. D'Ambra MN, Laraia DJ, Philbin DM, Watkins WD, Hilgenberg $\mathrm{AD}$, Buckley MJ. Prostaglandin $\mathrm{E}_{1}$ : a new therapy for refractory right heart failure and pulmonary hypertension after mitral valve replacement. J THORAC CARDIOvaSC SuRG 1985:89:567-72.

6. Gaines WE, Pierce WS, Prophet GA, Holtzman K. Pulmonary circulatory support. J THORAC CARDIOVASC SURG 1984; 88:958-64.

7. Swanson MJ, Fobaz AG, Jung JY. Successful treatment of right ventricular failure with atrial septostomy. Chest 1987; 92:950-2.

8. Carpals JM, Padro JM, Camara MI, Aris A, Bonin O. Creation of an atrial septal defect for acute postperfusion right ventricular failure. Ain Thorac Surg 1987;43:435-6.

9. Rich S, Lam W. Atrial septostomy as a palliative therapy for refractory primary pulmonary hypertension. Am J Cardiol 1983;51:1560-3.

10. Nihill MR, O'Laughlin MP, Mullins LE. Blade and balloon atrial septostomy is effective palliation for terminal cor pulmonale. Am J Cardiol 1987;60:683-7.

11. Laks H, Billingsley AM. Advances in the treatment of pulmonary atresia with intact ventricular septum. Cardiol Dis $1987 ; 7: 387-98$
12. Ad N, Barak J, Birk E, Diamant S, Vidne BA. A one-way, valved, atrial septal patch in the management of postoperative right heart failure: animal study. J THORAC CARDIOVASC SURG 1994;108:134-9.

13. Alexander JA, Rembert WC, Sealy WC, Greenfield JC. Shunt dynamics in experimental atrial septal defect in dogs. J Appl Physiol 1975;29:281-6.

14. Douglas JE, Rembert WC, Sealy WC, Greenfield JC. Factors affecting shunting in experimental atrial septal defect in dogs. Circ Res 1969;24:493-505.

15. de Leval MR, Bull C, Stark J, Anderson RH, Taylor JFN, Macartney FJ. Pulmonary atresia and intact ventricular septum: surgical management based on a revised classification. Circulation 1982;66:272-80.

16. Outcome in neonatal pulmonary atresia and intact ventricular septum: multiinstitutional study. J THORAC CARDIOvaSC SURG 1993;105:406-27.

17. Freedom R. How can something so small cause so much grief? Some thought of the undeveloped right ventricle in pulmonary atresia and intact ventricular septum. J Am Coll Cardiol 1992;4:1038-40.

18. Laks H, Pearl JM, Drinkwater DC, et al. Partial biventricular repair of pulmonary atresia and intact ventricular septum. Circulation 1992;86(5 Suppl):II159-66.

19. Kirklin JW, Barratt-Boyes BG. Cardiac surgery. New York: Churchill Livingstone, 1993:892.

20. Nakata S, Imai Y, Yakanashi $Y$, et al. A new method for quantitative standardization of cross sectional areas of the pulmonary arteries in congenital heart diseases with decreased pulmonary blood flow. J THORAC CARDIOVASC SURG 1984;88:610-9.

21. Gustafson RA, Murray GF, Nardon HE, Hill RL, Rozar GE. Early primary repair of tetralogy of Fallot. Ann Thorac Surg 1988;45:373-85

22. Kirklin JW, Barratt-Boyes BG. Cardiac surgery. New York: Churchill Livingstone, 1993:638-9.

23. Steele PM, Fuster V, Cohen M, Ritter DG, McGoon DC. Isolated atrial septal defect with pulmonary vascular obstructive disease-long term follow-up and prediction of outcome after surgical correlation. Circulation 1987;76:1037-42.

24. Craig RJ, Selzer A. A natural history and prognosis of atrial septal defect. Circulation 1968;37:805-15.

25. Kirklin JW, Barratt-Boyes BG. Cardiac surgery. New York: Churchill Livingstone, 1993:800-2.

26. Heath D, Edwards JE. The pathology of hypertensive pulmonary vascular disease. Circulation 1958;18:533-46.

27. Rabinovich M, Keane JF, Norwood WI, Castaneda AR, Reid L. Vascular structure in lung tissue obtained at biopsy correlated with pulmonary hemodynamic findings after tepair of congenital heart defects. Circulation 1984;69:655-67.

28. Brans YW, Dweck HS, Havis HB, et al. Effect of open heart surgery on the body composition of infants and young children. Pediatr Res 1981;15:1024-8.

29. Laks H. The partial Fontan procedure: a new concept and its clinical application [Editorial]. Circulation 1990;82:1866-7.

30. Stark J, de Leval M. Surgery for congenital heart defect. New York: WB Saunders, 1994:394.

31. Kirklin JW, Barratt-Boyes BG. Cardiac surgery, New York: Churchill Livingstone, 1993:963. 